Article

\title{
Surface Urban Heat Island in Middle City: Spatial and Temporal Characteristics
}

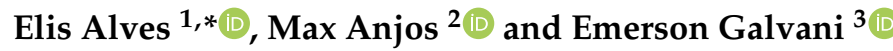 \\ 1 Instituto Federal de Educação, Ciência e Tecnologia Goiano, Campus Ceres, Rod. 154, Km 3, Zona Rural, \\ Ceres, Goiás 76300-000, Brazil \\ 2 Laboratory of Climatology-Laboclima, Department of Geography, Federal University of Paraná (UFPR), \\ Curitiba 81531-990, Brazil; maxanjos@campus.ul.pt \\ 3 Faculty of Philosophy, Literature and Humanities (FFLCH), University of São Paulo (USP), \\ São Paulo 05508-080, Brazil; egalvani@usp.br \\ * Correspondence: elis.alves@ifgoiano.edu.br
}

Received: 18 September 2020; Accepted: 29 October 2020; Published: 31 October 2020

check for updates

\begin{abstract}
Currently, cities have aroused the interest of researchers due the local climate change caused by the surface urban heat island (SUHI) effect. The impact of anthropogenic land use and cover changes has led to more frequent intense SUHI, with direct consequences on urban quality of life. Therefore, this research aims at analyzing the influences of natural and anthropogenic variables on the seasonality and spatial SUHI intensity in a Brazilian city, using remote sensing data and analysis of several physical parameters. Results show that the city of São Carlos has an SUHI mosaic and surface urban freshness island (SUFI). On average, $86 \%$ of the urban area presented a SUHI, whilst most SUFIs are located near watercourses, parks, slopes and valley bottoms, revealing the effects of green areas and relief on creation of microclimates. The SUHI showed significant seasonal variability.
\end{abstract}

Keywords: urban climate; spatial modeling; seasonality; planning

\section{Introduction}

Currently, cities have increasingly aroused the interest of researchers for the quality of life in the urban environment. Concerns about climatic conditions of metropolises have led several scholars to conduct research on this theme [1-9].

Studies conducted in the urban atmosphere have shown that cities generate a climate of their own, as result of the interference of various factors that occur within urban boundaries, that alters the climate at a local or regional scale [10]. In cities, changes in land surface temperatures are mainly due to building concentration, waterproofing by the pavement of streets and avenues, increases in the flow of people and automobiles and decreases in the vegetation cover. Such changes reverberate both local and regional climatic effects, depending on the size of the respective urban area [6,11-13].

The most prominent feature of urban climate is the urban heat island (UHI) phenomenon. The surface urban heat island (SUHI) [14] is a type of UHI and occurs over the surface envelope mediated by the changes in the surface temperature between urban and rural areas [15-17]. The UHI has been assessed by using meteorological observations from the mobile transects, near surface networks [7] [18,19], and climate classifications [20]. With the advance of new geospatial technologies, researchers have increasingly used remote sensing data (e.g., satellite imagery) to study SUHI [6,21-23]. Satellite remote sensing covers large areas and provides a direct and consistent way to examine the thermal environment of cities large [7,8,24-26].

The SUHI causes high summer temperatures and leads to serious health problems associated with heat, such as human thermal discomfort [27-30]. Therefore, mitigating SUHIs is critical for 
the management of urban space. The spatialization of differences between intra-urban and rural temperatures may offer subsidies to combat the magnitude of heat islands [31]. The SUHI simulations have been used in numerous studies [32-35], so that such simulations may provide prospects for reordering a territory compared with real data or based on observations of other studies,

The SUHI is largely influenced by a number of natural and anthropogenic factors, which includes city size and population impermeable surfaces (low albedo, decreased evapotranspiration), topography, anthropogenic heat and weather conditions [13,35-38]. Quantifying SUHI intensity and their independent variables is very important to improve the quality of life and achieve sustainable development of the city [22]. While most studies on UHI and SUHIs focus on large cities, the overall objective of this research was to investigate the SUHI intensity in a southeastern Brazilian city. We aim to (i) verify the seasonal and spatial variability of SUHI and (ii) discuss the relations between natural and anthropogenic variables that favor the development of the SUHI.

\section{Study Area}

The municipality of São Carlos, located in the state of São Paulo (Figure 1), is a transition region between the Cerrado biome and the Atlantic Forest. The climate is controlled by equatorial, tropical and polar masses [39]. Seasonality is well defined, with dry periods from April to September and humid periods from October to March. The monthly average temperature is $20.5^{\circ} \mathrm{C}$, the highest monthly average temperature occurs in February $\left(23^{\circ} \mathrm{C}\right)$ and January $\left(22.9^{\circ} \mathrm{C}\right)$ and the lowest average temperature occurs in July $\left(16.9^{\circ} \mathrm{C}\right)$ and June $\left(17^{\circ} \mathrm{C}\right)$ [40]. Rainfalls have a complex inter-annual variability. The average rainfall is $1528.1 \mathrm{~mm}$, with a standard deviation of $288.8 \mathrm{~mm}$. However, there may be exceptional rainfalls: the minimum rainfall recorded is 1143.4 and the maximum is $2486.7 \mathrm{~mm}[41]$.

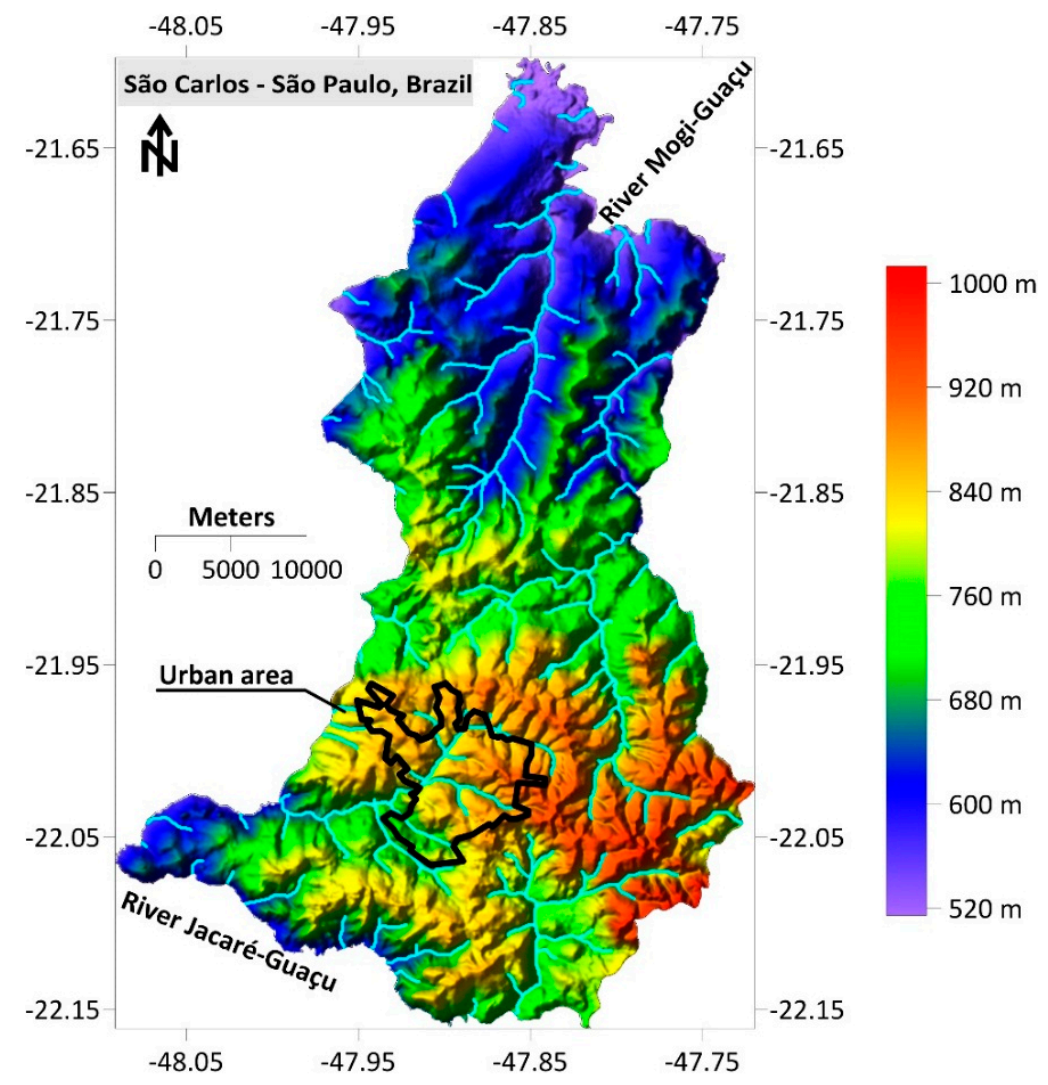

Figure 1. Hypsometric map of São Carlos. 
São Carlos is geomorphologically located on the western edge of the Basaltic Cuestas, near the Western Plateau and the Peripheral Depression. Thus, the relief of the city comprises isolated tables and hills, which are the result of an intense erosion caused by rivers that deeply carved the plateau. The altitude has a range of $480 \mathrm{~m}$. The lowest altitudes are around $775 \mathrm{~m}$ in valleys to the west of the main urban area, whilst the highest altitudes of $910 \mathrm{~m}$ are located to the east in a plateau [42].

The soils of the São Carlos are highly correlated with the relief and lithology shapes. There are predominantly clayey soils at the highest levels; shallow soils and rocky outcrops on cliffs; and medium textured soils (clay content between 15\% and 35\%) in lower altitudes areas. In the latter, there are also extensive areas of sandy and deep soils. Therefore, the city is characterized by high permeability soils consisting mostly of Red-Yellow Latosol and deep quartz sand with sandy characteristics [42].

The original vegetation of the region is the Cerrado, characterized by a herbaceous-woody and herbaceous-shrub forest formation with evergreen trees [42]. This type of vegetation is associated with an almost flat topographic sandy terrain extending to the north to the banks of the Mogi-Guaçu River and to the south to the edges of the Jacaré-Guaçu River valley. However, there is currently little original vegetation due to most non-urbanized areas being occupied by pastures, plantations, reforestation and mining [42].

In 2018, the population of São Carlos was estimated at 249,415 inhabitants [43]. However, the urban drainage, the road system and leisure areas did not keep up with the city's expansion, as $98.4 \%$ of the households have adequate sanitation, $89.2 \%$ of urban households are on public roads with forestation, and $34.2 \%$ of urban households are on public roads with an adequate urbanization (manholes, sidewalks, pavement and curbs). The city has also expanded without taking into account environmental, climatic, geological and topographical factors [44,45], leading to numerous social and environmental problems, such as floods, landslides, disorderly construction and high temperatures associated with UHI.

\section{Materials and Methods}

Figure 2 shows succinctly the steps to be performed in this research. This methodological procedure was elaborated based on several researches, seeking the most appropriate method for each step.

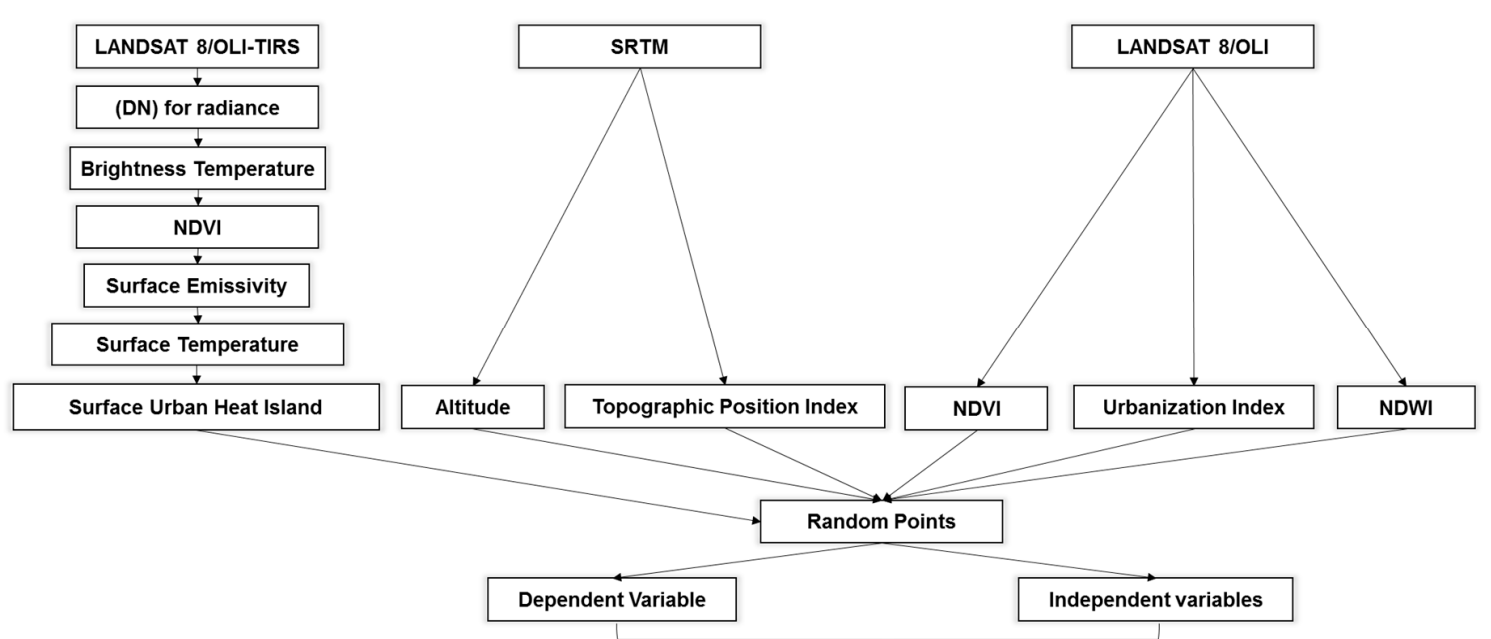

Figure 2. Methodological procedure for the calculation and analysis of surface urban heat island (SUHI).

To calculate the SUHI (dependent variable), six steps are required. Land Remote Sensing Satellite (LANDSAT) 8 and Shuttle Radar Topography Mission (SRTM) images were used in the period between 2015 and 2017 (Tables 1 and 2). All available images had reduced cloud cover with a maximum of $10.45 \%$ (Table 1). The images were generated at the same time with a discrepancy of less than two minutes, which ensures comparison over the years. All images had excellent quality, with a value of 
nine on a scale from zero to ten, so that zero means poor quality and ten means excellent quality. The weather conditions for each image acquisition campaign are observed in Table 2. Relative humidity was high (above 86\%) on 23 April 2015 and 14 July 2016, while the average air temperature was below $30{ }^{\circ} \mathrm{C}$ on all occasions. The highest wind speed was $7.23 \mathrm{~m} / \mathrm{s}$.

Table 1. Methodological procedure for modeling surface urban heat islands.

\begin{tabular}{ccccccc}
\hline Image & Date & Time (UTC) & $\begin{array}{c}\text { Cloud } \\
\text { Cover (\%) }\end{array}$ & $\begin{array}{c}\text { Image } \\
\text { Quality }\end{array}$ & Path/Raw & $\begin{array}{c}\text { Spatial } \\
\text { Resolution (m) }\end{array}$ \\
\hline 1 & 23 April 2015 & $13: 09: 12$ & 10.46 & 9 & $220 / 075$ & 30 OLI/100 TIRS \\
2 & 9 May 2015 & $13: 08: 57$ & 0.10 & 9 & $220 / 075$ & 30 OLI/100 TIRS \\
3 & 10 June 2015 & $13: 09: 07$ & 0.01 & 9 & $220 / 075$ & 30 OLI/100 TIRS \\
4 & 28 July 2015 & $13: 09: 29$ & 0.07 & 9 & $220 / 075$ & 30 OLI/100 TIRS \\
5 & 13 August 2015 & $13: 09: 34$ & 0.01 & 9 & $220 / 075$ & 30 OLI/100 TIRS \\
6 & 29 September 2015 & $13: 09: 40$ & 0.01 & 9 & $220 / 075$ & 30 OLI/100 TIRS \\
7 & 16 October 2015 & $13: 09: 53$ & 1.95 & 9 & $220 / 075$ & 30 OLI/100 TIRS \\
8 & 9 April 2016 & $13: 09: 29$ & 0.00 & 9 & $220 / 075$ & 30 OLI/100 TIRS \\
9 & 14 July 2016 & $13: 09: 49$ & 0.01 & 9 & $220 / 075$ & 30 OLI/100 TIRS \\
10 & 30 July 2016 & $13: 09: 53$ & 1.06 & 9 & $220 / 075$ & 30 OLI/100 TIRS \\
11 & 2 October 2016 & $13: 10: 07$ & 1.57 & 9 & $220 / 075$ & 30 OLI/100 TIRS \\
12 & 23 February 2017 & $13: 09: 46$ & 0.10 & 9 & $220 / 075$ & 30 OLI/100 TIRS \\
13 & 3 September 2017 & $13: 09: 59$ & 0.04 & 9 & $220 / 075$ & 30 OLI/100 TIRS \\
14 & 19 September 2017 & $13: 10: 01$ & 0.52 & 9 & $220 / 075$ & 30 OLI/100 TIRS \\
15 & 5 October 2017 & $13: 10: 07$ & 0.00 & 9 & $220 / 075$ & 30 OLI/100 TIRS \\
\hline
\end{tabular}

Table 2. Daily average weather conditions on the date of image acquisition.

\begin{tabular}{cccccc}
\hline Date & $\begin{array}{c}\text { Air Temperature } \\
\left({ }^{\circ} \mathbf{C}\right)\end{array}$ & $\begin{array}{c}\text { Relative } \\
\text { Humidity }(\mathbf{\%})\end{array}$ & $\begin{array}{c}\text { Wind Speed } \\
\mathbf{( m / s )}\end{array}$ & $\begin{array}{c}\text { Atmospheric } \\
\text { Pressure }(\mathbf{h P a})\end{array}$ & $\begin{array}{c}\text { Solar Radiation } \\
\left(\mathbf{W} / \mathbf{m}^{\mathbf{2}} / \mathbf{d a y}\right)\end{array}$ \\
\hline 23 April 2015 & 23.2 & 87.3 & 2.50 & 927.2 & 493.69 \\
9 May 2015 & 21.0 & 76.0 & 1.18 & 930.2 & 325.71 \\
10 June 2015 & 21.1 & 71.8 & 0.63 & 929.2 & 304.55 \\
28 July 2015 & 19.7 & 67.0 & 1.48 & 930.1 & 314.79 \\
13 August 2015 & 20.7 & 55.5 & 3.22 & 931.7 & 367.37 \\
29 September 2015 & 20.9 & 73.3 & 3.54 & 932.4 & 417.01 \\
16 October 2015 & 28.4 & 54.0 & 3.05 & 929.4 & 440.34 \\
9 April 2016 & 27.0 & 66.8 & 2.97 & 925.1 & 385.18 \\
14 July 2016 & 20.9 & 86.5 & 3.03 & 925.4 & 302.54 \\
30 July 2016 & 17.7 & 66.8 & 2.84 & 930.9 & 300.92 \\
2 October 2016 & 22.7 & 57.3 & 7.23 & 929.6 & 521.31 \\
23 February 2017 & 26.4 & 63.8 & 3.00 & 927.6 & 499.75 \\
3 September 2017 & 21.8 & 40.8 & 4.67 & 934.1 & 456.64 \\
19 September 2017 & 23.8 & 45.0 & 4.50 & 929.8 & 420.57 \\
5 October 2017 & 27.2 & 51.5 & 3.26 & 928.4 & 426.64 \\
\hline
\end{tabular}

\subsection{Dependent Variable}

\section{Procedures for Calculation of the SUHI}

LANDSAT data are freely available for download on the website of the United States Geological Survey (USGS) [46]. LANDSAT satellite sensors have been monitoring the Earth for over four decades, providing data continuity during this period $[47,48]$. The first series of this satellite was launched in 1972, named LANDSAT 1. Since then, there have been eight LANDSAT satellites. Among all eight, LANDSAT 6 failed to reach orbit and fell to the Earth in 1993. The other satellites were successful, and provided the researchers with a large amount of data used in many studies $[47,49]$.

The calculation of the SUHI was performed in six steps (Figure 2), as follows: (i) was to convert the digital numbers into radiance; (ii) to calculate brightness temperature; (iii) to calculate the NDVI (Normalized Difference Vegetation Index); (iv) to estimate the surface emissivity using the values 
obtained by the NDVI; (v) after estimating emissivity, to determine the corrected surface temperature, which was later transformed into SUHI in the sixth step, as suggested by Ndossi and Avdan [47,48].

\section{Step 1: Digital Numbers (DN) for Radiance}

Thermal data from LANDSAT satellite sensor images are stored in digital numbers (DN). DNs are pixels that have not yet been calibrated and represent different levels of radiance in the raster image. After obtaining satellite images, the first step converted DN into spectral radiance using data from the LANDSAT 8 satellite TIRS sensor by applying the Equation (1) [50]:

$$
L_{\lambda}=M_{L} \times Q_{c a l}+A_{L}-O_{i}
$$

where $L_{\lambda}$ is the spectral radiance at $W /\left(m^{2} \times s r \times \mu m\right)$ at the top of the atmosphere. $M_{L}$ is the multiplicative scaling factor of band 10. $Q_{c a l}$ is the quantized value calibrated by the pixel in DN. $O_{i}$ is the USGS published corrections for TIRS band calibration.

Step 2: Brightness Temperature

The brightness temperature is calculated by Equation (2) [50].

$$
B T=\frac{K_{2}}{\ln \left(\frac{K_{1}}{L_{\lambda}}+1\right)}
$$

where $B T$ is the brightness temperature in $(K), L_{\lambda}$ is the spectral radiance at the top of the atmosphere, $K_{1}$ is a constant value for conversion to thermal band, as is $K_{2}$.

Step 3: NDVI Calculation

Following the above calculations, the NDVI was calculated by obtaining the ratio between the difference in reflectance measurement in the near $\left(\rho_{5}\right)$ and red $\left(\rho_{4}\right)$ infrared channels, and the sum of these channels [51] (Equation (3)):

$$
N D V I=\frac{\rho_{5}-\rho_{4}}{\rho_{5}+\rho_{4}}
$$

NDVI is an indicator of the quantity and condition of green vegetation. The values range from -1 to +1 . Positive values are obtained some type of vegetation areas and vary according to the photosynthetic activity of the plants and its density. In the water surfaces, the NDVI is generally lower than zero $[23,52,53]$.

Step 4: Determination of Earth's Surface Emissivity

Terrestrial surface emissivity was estimated using the NDVI values. According to Zhang, Wang and Li [54], when the NDVI of an area is known, emissivity can be estimated. Thus, the emissivity of a pixel was estimated by classifying the pixels according to the class into which they fit (Table 3). When a pixel obtained a NDVI value below -0.185 , the emissivity value was 0.955 and the NDVI value was higher than or equal to -0.185 and lower than 0.157 , the emissivity of 0.985 was attributed to the pixel. When NDVI was higher or equal to 0.157 and lower than or equal to 0.727 , a logarithmic relation between NDVI and emissivity was used [47]. Finally, when the NDVI was higher than 0.727 , a value of 0.990 was assigned to the pixel (Table 3). 
Table 3. NDVI (Normalized Difference Vegetation Index)-based algorithm [47].

\begin{tabular}{cc}
\hline NDVI & Land Surface Emissivity (LSE) \\
\hline$N D V I<-0.185$ & 0.995 \\
$-0.185 \leq N D V I<0.157$ & 0.985 \\
$0.157 \leq N D V I \leq 0.727$ & $1.009+0.047 \times \ln (N D V I)$ \\
$N D V I>0.727$ & 0.990 \\
\hline
\end{tabular}

Step 5: Surface Temperature Correction

After estimating the emissivity of the soil surface, the brightness temperature correction was performed, using the Planck's function, that corrects the emissivity of a surface compared to a black body $[55,56]$, according to the Equation (4):

$$
L S T=\frac{B T}{\left\{1+\left[\frac{\lambda \times B T}{\rho}\right] \times \ln \varepsilon\right\}}
$$

where $L S T$ is the surface temperature $(\mathrm{K}), B T$ is the brightness temperature $(\mathrm{K}), \lambda$ is the wavelength of emitted radiation, $\rho$ is $(h \times c \div \sigma)=1.438 \times 10^{-2} \mathrm{mK}: h$ is Planck's constant $\left(6.26 \times 10^{-34} \mathrm{Js}\right), c$ is the speed of light $(2.998 \times 108 \mathrm{~m} / \mathrm{s}), \sigma$ is Stefan Boltzmann's constant $\left(1.38 \times 10^{-23} \mathrm{JK}^{-1}\right)$, and $\varepsilon$ is the surface emissivity.

Step 6: Surface Temperature Transformation into SUHI

Usually, the intensity of the urban heat island (UHII) is measured using air temperature observations along transects or at fixed stations in the surrounding urban and rural areas [22,57]. However, the SUHI requires another meaning because data for it are obtained by remote sensing [23]. Thus, the SUHI was calculated as the difference in surface temperature of each pixel in the urban area by the average surface temperature of the rural area $[23,58,59]$ according to Equation (5):

$$
S U H I=B T_{U}-\overline{B T_{R}}
$$

where $B T_{U}$ is the surface temperature in each pixel of the urban area, and $B T_{R}$ is the average of the rural surface temperature obtained from a 1-km buffer from the urban boundaries (Figure 3). A positive value means the occurrence of a SUHI and a negative value represents surface urban freshness island (SUFI). There is no standardized method for delimiting the rural area buffer and measuring SUHIs. Alves [23] analyzed the seasonal and spatial variation of SUHI intensity in a small urban cluster in Brazil using a 500-m buffer; then he used 200-m and 500-m buffers to quantify the effects of watercourses and green areas on surface temperature. Cheval and Dumitrescu [60] used buffers of various sizes (1-7 km) to analyze summer SUHIs in Bucharest, Romania. Rasul et al. [59] used a 10-km buffer around of Erbil, Iraqi Kurdistan and determined the surface rural temperature. Debbage and Shepherd [61] set up a 50-km buffer to estimate SUHI intensity of the fifty most populous cities in the United States. Therefore, there is no soft definition of the size of the buffer or peri-urban areas. It is stipulated according to the specificity of the study area. Therefore, in this research, taking into consideration the relation between the size of the cities and the buffer size used in these works, we opted for a $1-\mathrm{km}$ buffer. 


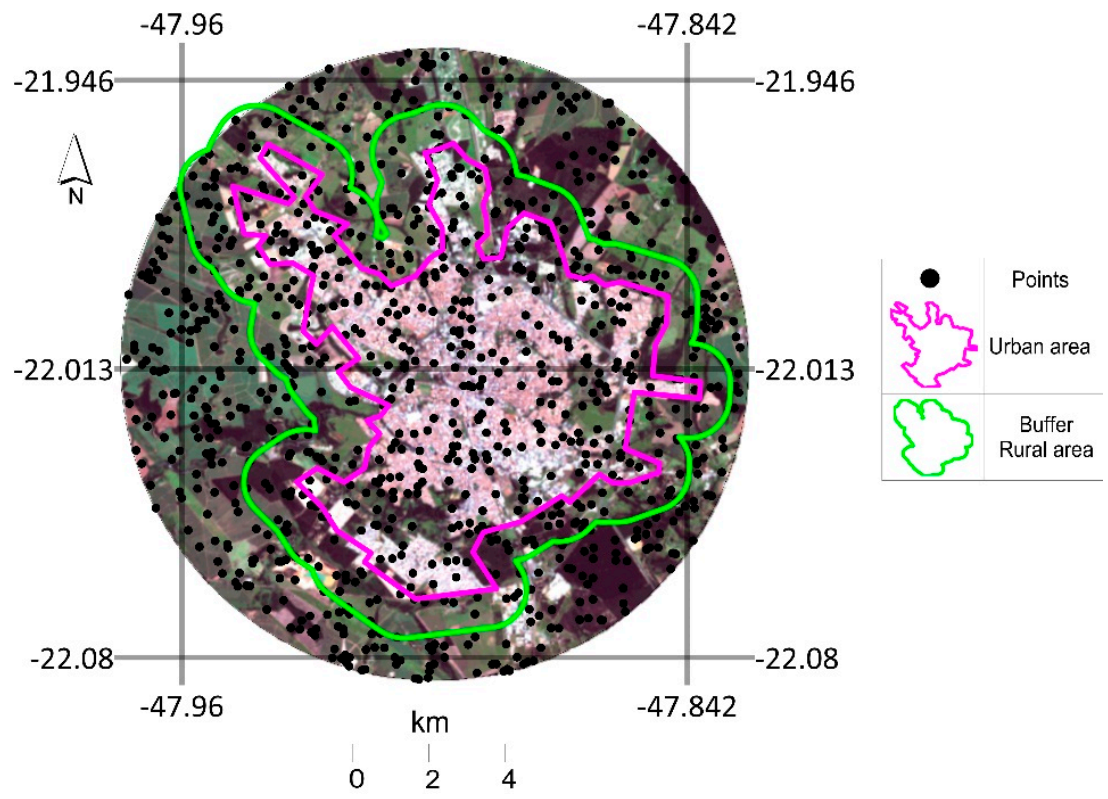

Figure 3. Random measuring points within the urban boundary and the rural buffer of São Carlos.

For modeling, we used data from 1000 random points within the buffers. This reduction in sampling was necessary due to the complexity of GWR calculation, which requires high memory and computational processing.

\subsection{Independent Variables}

The independent variables altitude and topographic position index were calculated using SRTM data. The variables UI, NDVI (obtained in Step 3) and NDWI were obtained using images of the LANDSAT 8 satellite.

\subsubsection{Altitude}

The altitude or height above mean sea level is a key factor that controls air temperature. Areas with different altitudes may cause variations in air temperature and atmospheric emissivity, which may cause variations in surface temperature [62]. We used data from the TOPODATA project [63], which offers free access to geomorphometric variables derived from SRTM data (Shuttle Radar Topographic Mission) for the entire Brazilian territory. Subsequently, these data were refined from the original spatial resolution from 3 arc-seconds $(\sim 90 \mathrm{~m})$ to 1 arc-second $(\sim 30 \mathrm{~m})$ per kriging.

\subsubsection{Topographical Position Index}

The Topographic Position Index (TPI), an algorithm created by Weiss [64], which calculates differences in the elevation between a central pixel (Z0) and the average elevation of its surroundings (Zm). The value of TPI expresses the contrast intensity [64,65].

The TPI allows for determining characteristics of the landscape taking into account the topographic attributes. Thus, the units defined are closely related to water flow conditions and surface dynamics [64].

The TPI is the difference between a cell elevation value and the average neighborhood altitude around these cells. Positive values mean that the cell is higher than its surroundings, while negative values mean it is lower. If it is significantly higher than the surrounding area, then it is likely to be near or on top of a hill or a ridge. Significantly low values suggest that the cell is near or at the bottom of a valley [64]. TPI values close to zero may mean either a flat area or a medium slope area.

The variation in the inclination and orientation of relief slopes, associated with variations in altitude, plays an important role in the distribution of calorific-luminous energy $[62,66]$. The radiative flow of an inclined slope may be more intense than others at a certain time of day, but the incidence of 
sunlight may be significantly lower in other periods. Likewise, the shading of buildings and trees, among others, are more expressive in flat areas [62,65].

\subsubsection{Urbanization Index}

The Urbanization Index (UI) is calculated using the bands 5 and 7 of the LANDSAT 8 satellite. This index was proposed by Kawamura, Jayamanna and Tsujiko [67] to estimate urbanization. It may vary from -1 to 1 : the higher the value, the greater the degree of urbanization, following the Equation (6):

$$
U I=\frac{\rho_{7}-\rho_{5}}{\rho_{7}+\rho_{5}} \times 100
$$

where $U I$ is the Urbanization index, $\rho_{7}$ is the reflectance of the band 7 and $\rho_{5}$ is the reflectance of the band 5 of the LANDSAT 8 satellite.

\subsubsection{Normalized Difference Water Index}

The Normalized Difference Water Index (NDWI) was developed by McFeeters [68], who purposes to delineate features in the aquatic environment and highlight their presence in the images. Water is important for the thermal balance because of its ability to absorb energy and release it slowly. The NDWI can be defined according to Equation (7):

$$
\mathrm{NDWI}=\frac{\rho_{3}-\rho_{5}}{\rho_{3}+\rho_{5}}
$$

where $\rho_{3}$ is the reflectance of the band 3 and $\rho_{5}$ is the reflectance of the band 5 of the LANDSAT 8 satellite. NDWI values range from -1 to 1 . The value zero is a threshold, i.e., the type of cover is considered water if NDWI $\geq 0$ and not water if NDWI $\leq 0$.

\section{Results and Discussion}

\subsection{SUHI in São Carlos}

Cities have a complex thermal system. Surface varieties are largely responsible for creating a mosaic of microclimates. In addition to the artificialization of the urban environment, natural issues, such as topography, also establish a direct relationship in the creation of microclimates $[6,9,12,35,69,70]$.

It is noteworthy that the mean value of any phenomenon should be carefully considered; it also masks some episodic specificities and makes the temporal patterns more evident. In the city of São Carlos, houses, buildings, pavements, roofs, streams, riparian forests and parks create a mosaic of microclimates influenced by both natural and anthropogenic characteristics (Figure 4).

The areas corresponding to Miguel Petroni Street (2), Tecumseh do Brasil Ltd.-Plant 2 (3), Vila Jacobucci (5), Jardim Ricetti (7), Tecumseh do Brasil Ltd.-Plant 1 (8), Aracy City (10), Antenor Garcia (12), Vila Boa Vista 1 (13) and the Shopping Center (14) presented, on average, the greatest SUHIs $\left(4^{\circ} \mathrm{C}\right.$ ). The areas 2, 5, 7, 10, 12 and 13 (Figure 4) consist of residential buildings, mostly with ceramic roofs, while the areas 3 and 8 correspond to industrial areas with fiber cement roofs. There is a shopping center in the area 15, which is a shopping area with ample parking space with an asphalt pavement. Therefore, in São Carlos, the greatest SUHIs were observed in areas built with materials of a high thermal conductivity and heat capacity (concrete and asphalt). According to Gartland [13], materials with a high thermal conductivity are better able to direct the absorbed thermal energy into their interior, and materials with a high heat capacity can store more energy without losing it to the environment: the more energy is stored, the greater the material temperature will be. 


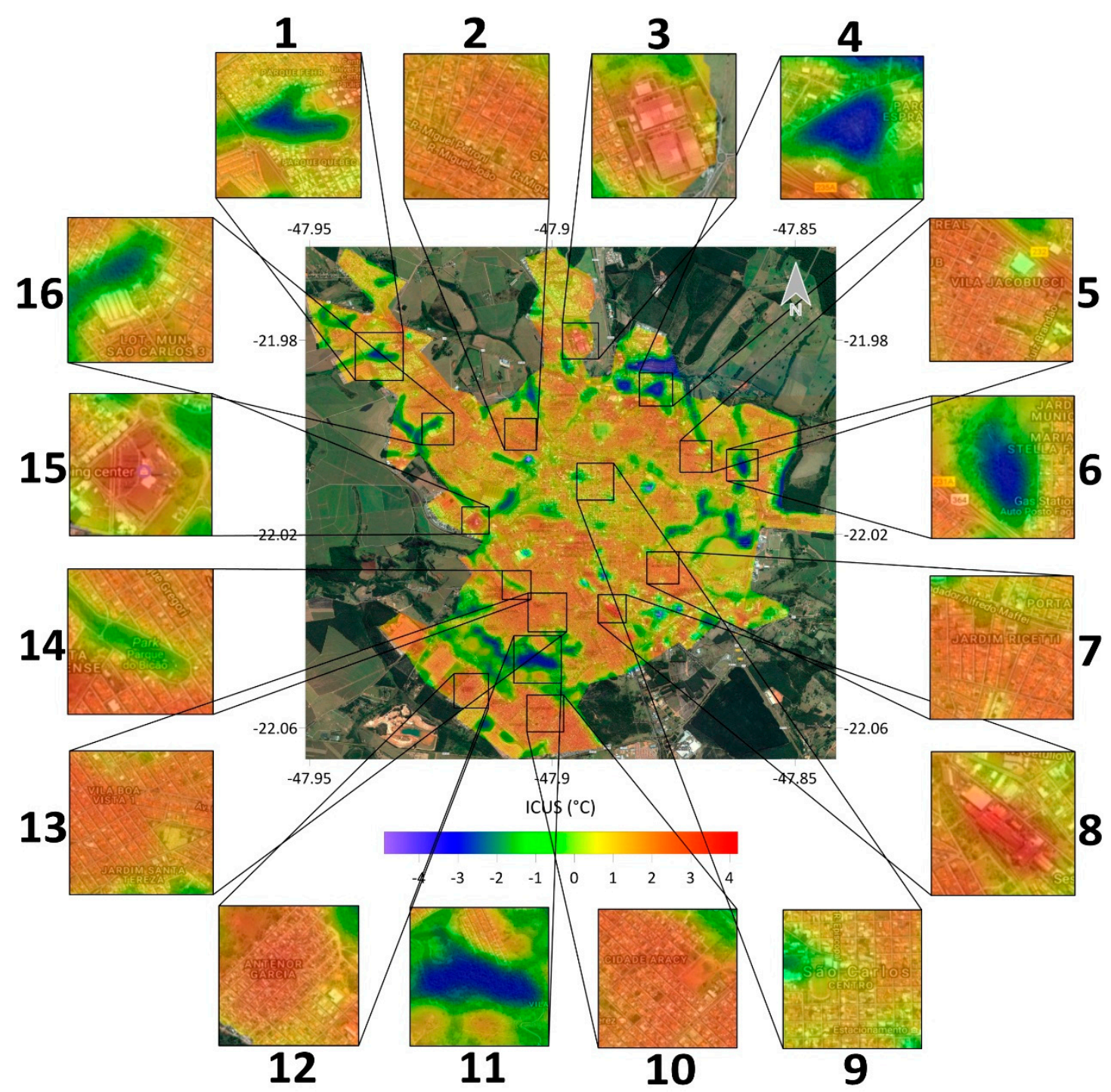

Figure 4. SUHI obtained from the average of all images (2015-2017).

However, in urban areas, some of them may have surface urban freshness islands (SUFI), also called negative SUHIs [23,71], due to the presence of green areas (parks, woods, riparian forest etc.) or the presence of surfaces with water. In São Carlos, the green areas located between the Quebec and Fehr Parks (1), São Carlos Ecological Park (4), a remnant green area west of Hermano Bomfim da Silva Street (6), riparian forests west of Vila Conceição (11), Bicão Park (14) and the riparian forest east of the University of São Paulo-campus 2 (16) are examples of the influence of green and humid areas on the surface temperature, and consequently on SUHIs. Refs. $[9,69,72]$ found a similar effect exerted by green areas. Urban parks have been considered an important part of urban vegetation because they are cooler than their surrounding areas, creating SUFI effect $[57,73]$.

There was a predominance of SUHI over SUFI in the urban area of São Carlos (Figure 5). The SUHI, on average, occupied an area of $52.6 \mathrm{~km}^{2}$, which means six times the area occupied by the SUFI $\left(8.5 \mathrm{~km}^{2}\right)$. This finding highlights a problem observed in several Brazilian cities: the lack of urban planning considering microclimate as a factor for spatial planning [19,23,74-76]. Most SUFIs are located near watercourses, parks, slopes and valley bottoms (Figure 5), revealing the effects of green areas and relief on SUHI intensity. A similar result was observed by Alves [77] and Lopes [78]. 


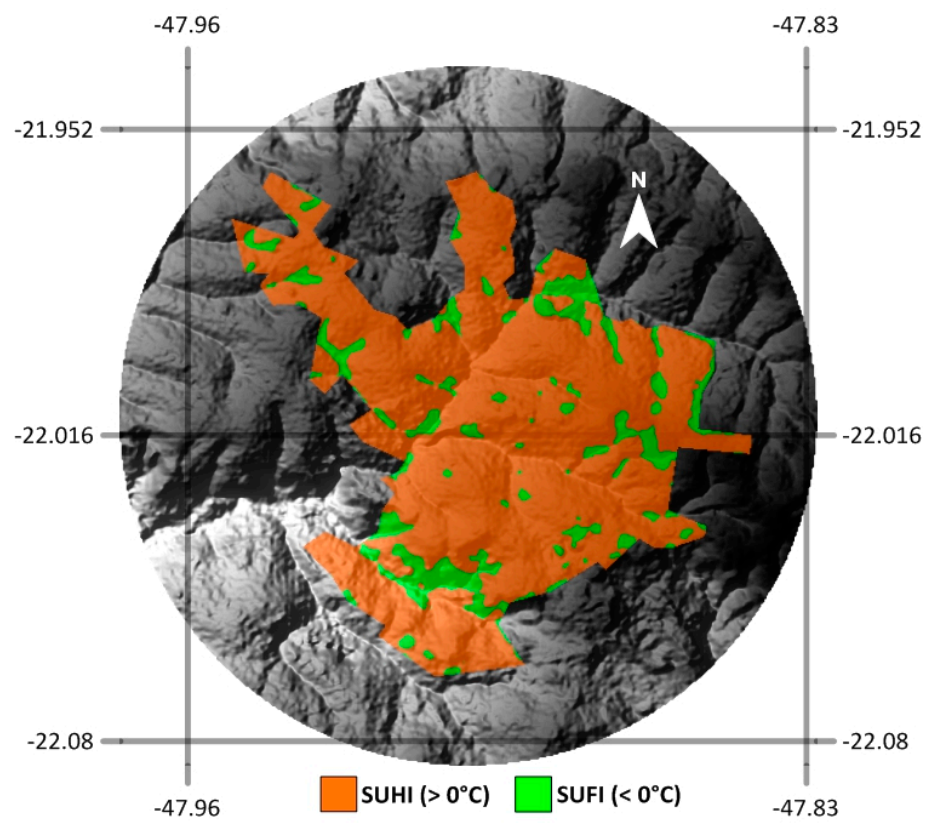

Figure 5. Area occupied by SUHI and surface urban freshness island (SUFI).

\subsection{Seasonality of Urban Surface Heat Islands}

The seasonality of SUHI has already been observed in several cities: Buyantuyev and $\mathrm{Wu}$ [79] in the Phoenix metropolitan region (United States), Haashemi et al. [80] in Tehran (Iran), Gémes et al. [16] in Szeged (Hungary), Rasul et al. [59] in Erbil (Iraq) and Alves et al. [23] in Ceres and Rialma (Brazil).

In the city of São Carlos, the seasonality of SUHIs was evident (Figure 6). Although, the development of UHIs and SUHIs is generally associated with urban expansion, increased human and industrial activities, geographical location, climate, urban materials, no-presence of vegetation, seasons and times of day and night may exert different effects [80]. Lazzarini et al. [81] reported the SUHI in Abu Dhabi, a city in the desert, and showed a reversal of what is considered a standard for SUHIs during the day: central areas had lower surface temperatures compared to the suburbs, with a daily difference of 5-6 K in summer and 2-3 K in winter. In contrast, the highest intensities of negative SUHIs were verified within the urban area during the winter in São Carlos.

The seasonal variation of SUHIs (Figure 6) results from changes in solar radiation intensity due to the earth's translational movement and the variation of Cerrado and pasture leaf areas, which follow the rhythm of rainfalls $[23,82]$. The highest SUHI intensities were observed in the summer, with SUHIs above $8{ }^{\circ} \mathrm{C}$. According to Buyantuyev and Wu [79], surface urban heat islands (SUHIs) exist at any time of the day. However, they are more intense closer to noon and during the summer.

The summer is the rainy season in São Carlos, where vegetation and pasture become denser due to a higher metabolic activity, as emphasized by the NDVI values. As a result, the urban and rural contrast is sharper, and the SUHI intensities tend to be higher. In late autumn and winter, there was little difference in the SUHIs intensity from urban to rural areas. In autumn, the amplitude of SUHI intensity was lower than in other seasons, ranging from -2.6 to $4.4{ }^{\circ} \mathrm{C}$ because, during this period, the Cerrado and pastures dry or lose their leaves to reduce the adverse effects of the lack of rainfalls. Besides that, green areas are known to decrease surface temperature due to shading and evaporative cooling $[83,84]$. 

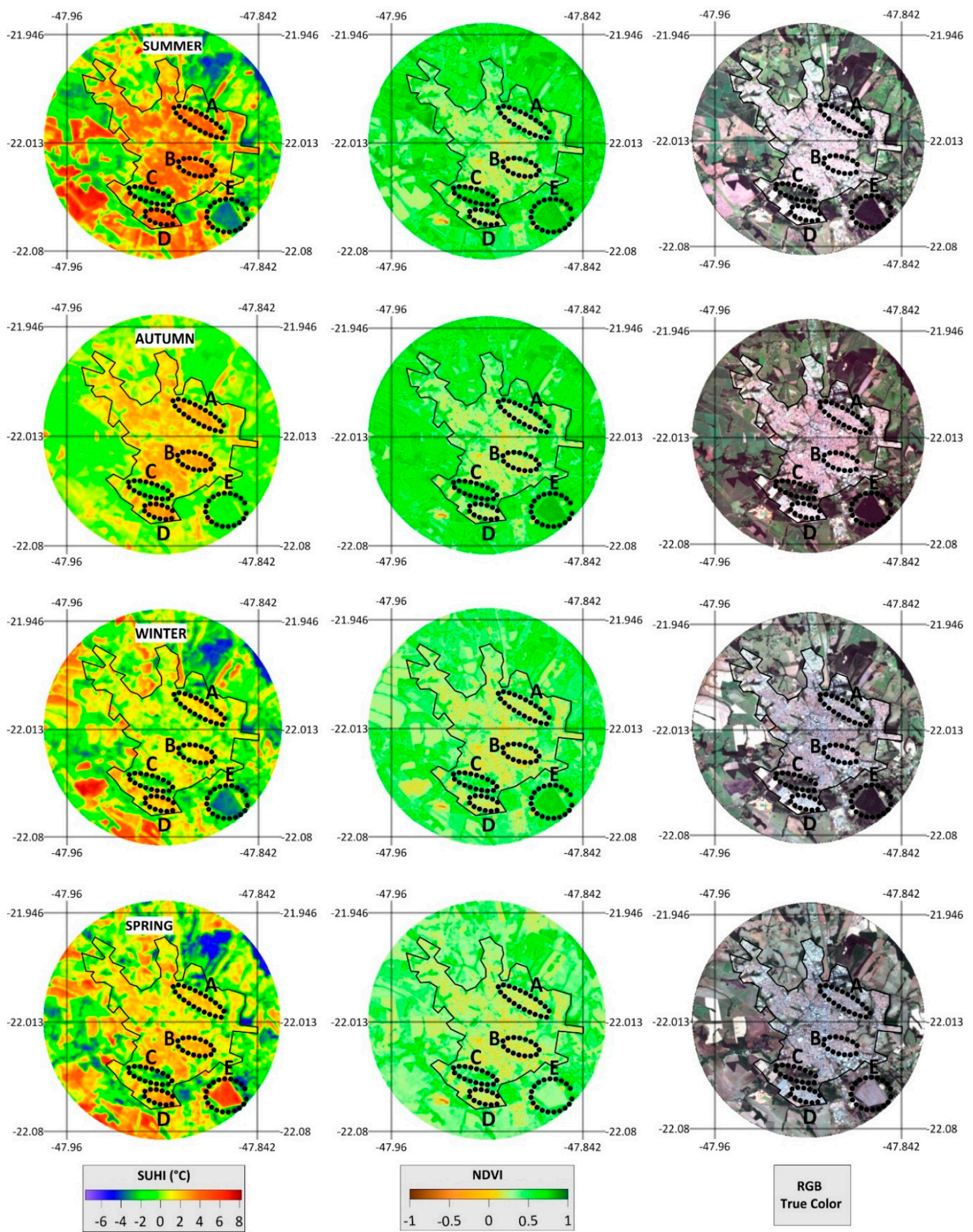

Figure 6. Urban surface heat islands, NDVI and RGB (Red, Green, Blue) images obtained in the summer, autumn, winter and spring. The sites A, B, C, D and E, represented by dashed ellipses, refer to areas that show different patterns in SUHI and NDVI intensity.

The sites A, B, C, D and E represent areas with different surface types. A, B and D are high urbanization sites, and the $C$ represents a green area with riparian forest, while the E eucalyptus plantation represents an area outside the urban limits. Regarding the sites $\mathrm{A}, \mathrm{B}$ and $\mathrm{D}$, all seasons presented SUHIs with a higher intensity in the summer. The site D had the greatest SUHI of $4.8^{\circ} \mathrm{C}$ (Figure 7). The winter was the season with the lowest SUHI intensities. The lowest NDVI values were observed at these sites. The site $C$ showed only SUFIs with a higher intensity in the summer 
$\left(-2.4^{\circ} \mathrm{C}\right)$ because of green area with riparian forests and a high NDVI, located in a valley bottom, which favors the absorption of solar radiation throughout the day, especially in the morning (Landsat 8 satellite passing time). Site $\mathrm{E}$ had the highest SUFIs, reaching $-3.4^{\circ} \mathrm{C}$ in the winter and $-3{ }^{\circ} \mathrm{C}$ in the summer. Unlike other areas, site E showed a change in its thermal pattern from SUFI to SUHI in spring. It nevertheless obtained the highest intensity among the sites $\left(5.5^{\circ} \mathrm{C}\right)$. This site was covered by eucalyptus. However, trees were cut in the spring, leaving the soil exposed and substantially changing the NDVI (from 0.73 to 0.3), confirming the effects of green areas on surface temperature and consequently on SUHI/SUFI intensity.
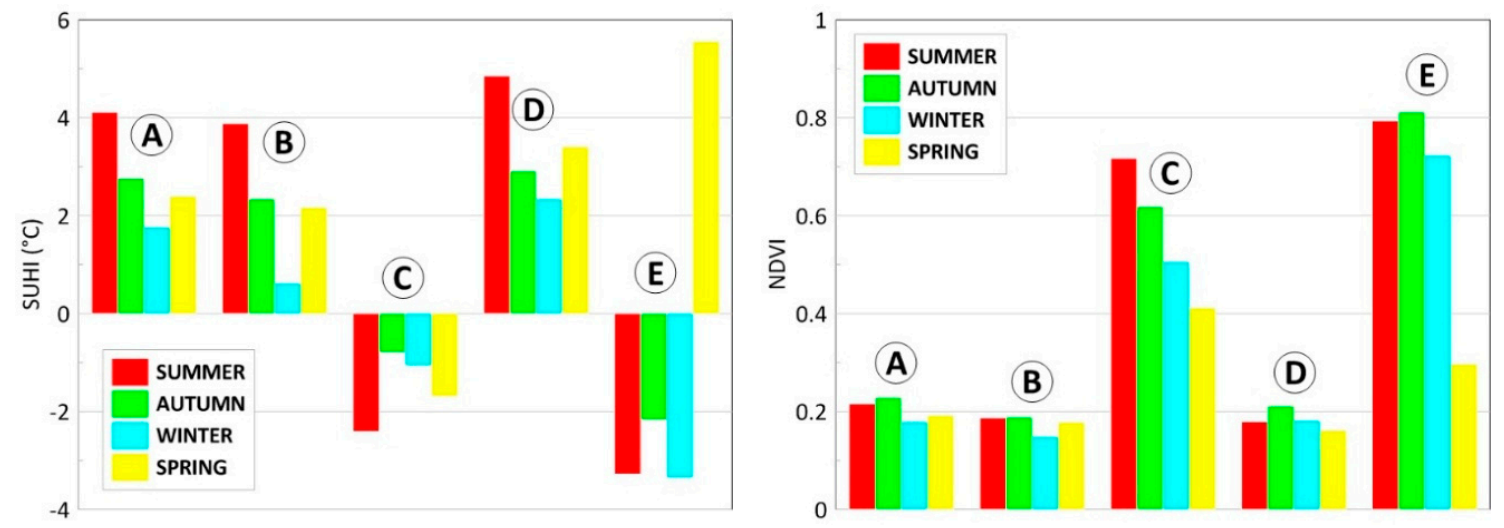

Figure 7. Variability of SUHI and NDVI at the sites A, B, C, D and E during the summer, autumn, winter and spring.

\subsection{Relationship between SUHI, UI, NDVI, NDWI and TPI}

In order to determine the correlation between SUHIs and natural and anthropogenic variables, a Pearson's correlation coefficient was performed. One thousand samples were randomly selected to investigate the relationship between SUHI and altitude, UI, NDVI, NDWI and TPI during the seasons. The results of the correlation analyses are summarized in Table 4 and Figure 8 . The correlation between the SUHI and the variables has a seasonal factor. The greatest variations occurred among the variables SUHI, UI and NDWI, i.e., variations of 0.55 and 0.23 in the coefficients, respectively. Seasonal variation may cause an inverse relationship: one season may show a positive correlation and the other a negative one. Haashemi et al. [80] observed that the relationship between NST (Normalized Surface Temperature) and the variables SVF (Sky Vision Factor), albedo, WS (Waterproof Surface) and altitude showed positive and negative correlations depending on the season and time. This change in the direction of significant correlations $(p$-value $<0.05)$ was not observed in this study because the variables used in one research study do not always have the same pattern as the SUHIs in other studies. The local settings of the urban site and the rural area create a complex system, varying their patterns in space and time.

Table 4. Pearson's correlation coefficient between SUHIs and altitude, UI, NDVI, Normalized Difference Water Index (NDWI) and Topographic Position Index (TPI) in different seasons.

\begin{tabular}{cccccc}
\hline & Summer & Autumn & Winter & Spring & Variation \\
\hline & SUHI & SUHI & SUHI & SUHI & SUHI \\
\hline Altitude & -0.08 & $0.08^{*}$ & -0.10 & 0.01 & -0.18 \\
UI & $0.88^{*}$ & $0.69^{*}$ & $0.35^{*}$ & $0.33^{*}$ & 0.55 \\
NDVI & $-0.85^{*}$ & $-0.84^{*}$ & $-0.69 *$ & $-0.73^{*}$ & -0.12 \\
NDWI & $0.82^{*}$ & $0.83^{*}$ & $0.59^{*}$ & $0.67^{*}$ & 0.23 \\
TPI & 0.04 & 0.04 & 0.02 & 0.04 & 0.01 \\
\hline
\end{tabular}

${ }^{*} p$-value $<0.05$. 

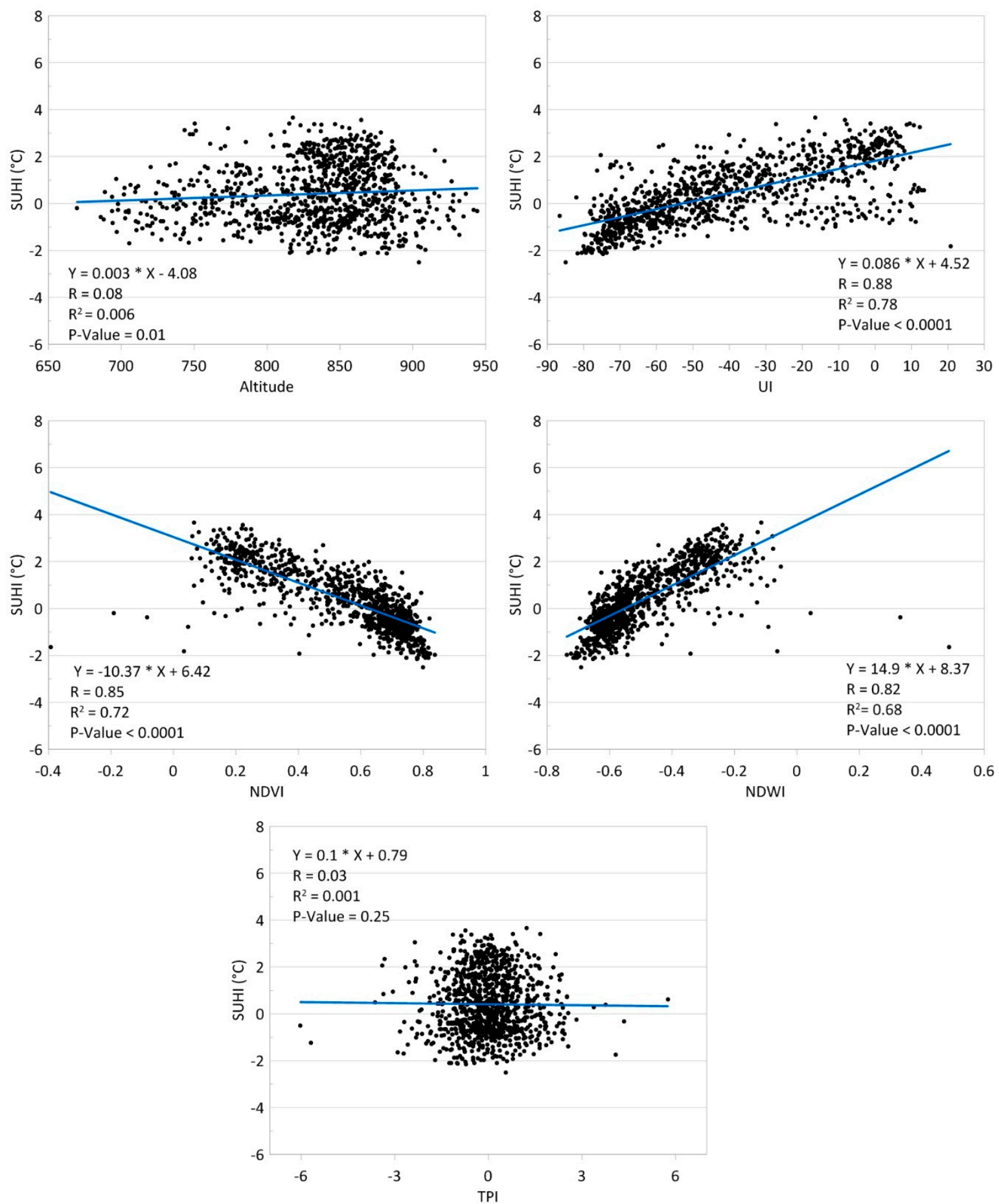

Figure 8. SUHI versus Altitude, UI, NDVI, NDWI and TPI scatter plots in the summer.

The correlation coefficient of SUHI with altitude was 0.08 in the fall, denoting a low correlation. However, the $p$-value was below the significance level of 0.05 . Great caution is required when interpreting $p$-values, as this measurement is greatly influenced by sample size. Large samples tend to result in low $p$-values, although the observed effect is not of great practical importance [85]. Altitude is an important geographical factor for air temperature variation. However, the relationship with SUHI variation was not equally observed (Table 4), since it is a surface phenomenon. Li et al. [62] showed that this relationship could occur due to the variation in atmospheric emissivity that occurs with the variation of altitude, which directly influences the radiation that reaches the surface. However, 
the differences in altitude in the urban area were not expressive at an atmospheric scale sufficient to establish a significant correlation.

A study conducted in Ljutomer (Slovenia) by Ivajnšič et al. [65] found a slightly positive relationship between mean air temperature and TPI, which means that convex areas are slightly warmer than concave areas of that city. In São Carlos, TPI showed no significant correlation in any season, as well as altitude. Therefore, although air temperature, surface temperature, UHI and SUHI are directly related, and the correlations of altitude and TPI did not extend to other phenomena.

The NDWI showed a positive and significant correlation with SUHI in all seasons. The highest correlation was observed in the summer and autumn (0.82 and 0.83) (Table 4 and Figure 8), which disagrees with the results of the Deilami et al. [86], Lee et al. [87] and Tyubee et al. [88], who found a negative association of SUHI and surface temperature with NDWI.

Green areas play an important role in radiation balance. NDVI is the most used index to diagnose the condition of the vegetation. Its relationship with NST and SUHI has been observed in several studies. The negative correlation is the most observed result $[79,89,90]$, corroborating the results found in this research. There were negative correlations in all seasons, which were more significant in the summer (Figure 8). However, it is possible to notice different results, such as in Lee et al. [87], who observed a negative relationship between NST and NDVI when NDVI was greater than zero and a positive relation when NDVI was lower than zero. Alves [23] found a similar result, noting that an NDVI equal to 0.2 was a divisor of the positive and negative relationship with NST; up to this value, the relation was positive, i.e., the higher the value of the NDVI, the higher the value of NST, while for a NDVI greater than 0.2, the relation was negative. Rasul et al. [91] observed negative relationships in the autumn and spring. However, the relationship was positive in the winter and non-significant in the summer. In a study by Sun and Kafatos [92], the correlations between NDVI and NST were generally positive in the winter and early spring. However, the NDVI-NST relationship was negative in the summer and autumn. Bala et al. [17] did not report a significant correlation.

All stations had significant correlations with UI, NDVI and NDWI (Table 4). The summer had the highest correlations (Table 4 and Figure 8), in which the effects of the artificial variable (UI) and natural variables (NDVI and NDWI) were more pronounced because of major contrasts between urban and rural areas.

\section{Conclusions}

The urbanization process has generated cities with diverse land use and covers according to the spatial, political, economic and social configuration of the region in which they are inserted. However, cities have developed a common feature: SUHI, a phenomenon that alters the energy balance and directly influences the local climate.

In the city of São Carlos, there was a predominance of SUHIs over SUFIs (Surface Urban Freshness Island). SUHIs, on average, occupied $86 \%$ of the urban area, while SUFIs occupied only $14 \%$. This finding confirms need for urban planning that takes into account the microclimate as an inseparable factor for sustainable development. Most SUFIs are located near watercourses, parks, slopes and valley bottoms, revealing the effects of green areas and relief on the SUFIs intensity.

The associations between SUHIs and all five independent variables (Altitude, UI, NDVI, NDWI and TPI) show significant seasonal variations. Linear relationships were observed for the variables NDVI, NDWI and UI.

Several limitations deserve to be discussed. First, this study did not include variables related to urban functions due to a lack of data in the models. The urban climate is an integrated product of a complex interactivity of urban form and urban function with the overlying atmosphere. Therefore, it is also important to address urban function, such as industrial and anthropogenic heat emission in modeling.

Despite the constant frequency of satellite sensor data sampling, in the case of Landsat 8, periods of heavy cloudiness prevent further spatiotemporal analysis of the urban thermal environment. In 
addition, the Landsat 8 satellite passes over study area, usually at 10 a.m., making intra-daily analysis impossible. Therefore, the results obtained must be interpreted carefully.

However, the relationship between SUHIs and urban landscape has a great seasonal variability. This seasonal effect is generally created through the seasonal variation of solar radiation and the landscape's biogeophysical properties. For example, evergreen trees are able to reduce exposure to cold air and wind. Deciduous trees are unable to do so. Conversely, evergreen trees intercept solar radiation and prevent it from reaching the surface, reducing the surface temperature.

Author Contributions: The contribution of the authors of this paper is as follows: conceptualization, E.A., E.G.; methodology, E.A., E.G.; data collection, E.A.; analysis and interpretation, E.A., E.G., M.A.; writing-review and editing, E.A., M.A.; visualization, E.A. All authors have read and agreed to the published version of the manuscript.

Funding: This research received external funding from the the Instituto Federal de Educação, Ciência e Tecnologia Goiano.

Acknowledgments: The authors would like to thank the University of São Paulo, where the post-doctorate was held, and also the Instituto Federal de Educação, Ciência e Tecnologia Goiano for the funding. Max Anjos held a post-doctoral fellowship with CAPES/PrInt (Brazilian Ministry of Education). The third author thanks the National Research Council of Brazil $(\mathrm{CNPq})$ for assistance through a research and productivity grant process number 304973 / 2017-3.

Conflicts of Interest: The authors declare no conflict of interest regarding the publication of this paper.

\section{References}

1. Oke, T.R. Canyon geometry and the nocturnal urban heat island: Comparison of scale model and field observations. J. Climatol. 1981, 1, 237-254. [CrossRef]

2. Souch, C.; Grimmond, S. Applied climatology: Urban climate. Prog. Phys. Geogr. 2006, 30, $270-279$. [CrossRef]

3. Coutts, A.M.; Beringer, J.; Tapper, N.J. Characteristics influencing the variability of urban $\mathrm{CO}_{2}$ fluxes in Melbourne, Australia. Atmos. Environ. 2007, 41, 51-62. [CrossRef]

4. Alcoforado, M.-J.; Andrade, H.; Lopes, A.; Vasconcelos, J. Application of climatic guidelines to urban planning. Landsc. Urban Plan. 2009, 90, 56-65. [CrossRef]

5. Zoulia, I.; Santamouris, M.; Dimoudi, A. Monitoring the effect of urban green areas on the heat island in Athens. Environ. Monit. Assess. 2009, 156, 275-292. [CrossRef] [PubMed]

6. Tarifa, J.R.; de Azevedo, T.R. Os Climas na Cidade de São Paulo: Teoria e Prática; GEOUSP-Coleção Novos Caminhos: São Paulo, Brazil, 2001; Volume 4.

7. Amorim, M.; Dubreuil, V.; Cardoso, R. Modelagem espacial da ilha de calor urbana em Presidente Prudente (SP)—Brasil. Rev. Bras. Climatol. 2015, 16, 29-45. [CrossRef]

8. Lombardo, M.A. Ilhas de Calor nas Metrópoles: O exemplo de São Paulo; HUCITEC: São Paulo, Brazil, 1985.

9. Alves, E.; Lopes, A. The Urban Heat Island Effect and the Role of Vegetation to Address the Negative Impacts of Local Climate Changes in a Small Brazilian City. Atmosphere 2017, 8, 18. [CrossRef]

10. De Monteiro, C.A.F. Teoria e Clima Urbano; Universidade de São Paulo: São Paulo, Brazil, 1976.

11. Alves, E.D.L.; Biudes, M.S. Análise da temperatura do ar e da umidade relativa: Estudo de microclimas. Interthesis 2012, 9, 139-156. [CrossRef]

12. Alves, E.; Anjos, M.; Lopes, A. Multitemporalidade das anomalias da temperatura de superfície: O caso da cidade de Iporá, Brasil. GOT J. Geogr. Spat. Plan. 2017, 5-21. [CrossRef]

13. Gartland, L. Heat Islands: Understanding and Mitigating Heat in Urban Areas; Routledge: London, UK, 2012.

14. Oke, T.R.; Mills, G.; Christen, A.; Voogt, J.A. Urban Climates; Cambridge University Press: Cambridge, UK, 2017.

15. Ma, Y.; Kuang, Y.; Huang, N. Coupling urbanization analyses for studying urban thermal environment and its interplay with biophysical parameters based on TM/ETM+ imagery. Int. J. Appl. Earth Obs. Geoinf. 2010, 12, 110-118. [CrossRef]

16. Gémes, O.; Tobak, Z.; van Leeuwen, B. Satellite Based Analysis of Surface Urban Heat Island Intensity. J. Environ. Geogr. 2016, 9, 23-30. [CrossRef] 
17. Bala, R.; Prasad, R.; Yadav, V.P.; Sharma, J. A comparative study of land surface temperature with different indices on heterogeneous land cover using Landsat 8 data. In The International Archives of the Photogrammetry, Remote Sensing and Spatial Information Sciences; International Society of Photogrammetry and Remote Sensing: Hannover, Germany, 2018; Volume 42, pp. 20-23.

18. Voogt, J.A.; Oke, T.R. Thermal remote sensing of urban climates. Remote Sens. Environ. 2003, 86, 370-384. [CrossRef]

19. Minaki, C.; Amorim, M.C.C.T. Análise da temperatura e da umidade relativa do ar na primavera-verão em Araçatuba/SP. Rev. Bras. Climatol. 2014, 13, 236-247. [CrossRef]

20. Stewart, I.D.; Oke, T.R. Local Climate Zones for Urban Temperature Studies. Bull. Am. Meteorol. Soc. 2012, 93, 1879-1900. [CrossRef]

21. Alves, E.D.L.; Biudes, M.S. Method for determining the footprint area of air temperature and relative humidity. Acta Sci. Technol. 2013, 35, 187-194. [CrossRef]

22. Lopes, A.; Alves, E.; Alcoforado, M.J.; Machete, R. Lisbon Urban Heat Island Updated: New Highlights about the Relationships between Thermal Patterns and Wind Regimes. Adv. Meteorol. 2013, 1-11. [CrossRef]

23. Alves, E. Seasonal and Spatial Variation of Surface Urban Heat Island Intensity in a Small Urban Agglomerate in Brazil. Climate 2016, 4, 61. [CrossRef]

24. Xu, Y.; Qin, Z.; Wan, H. Spatial and Temporal Dynamics of Urban Heat Island and Their Relationship with Land Cover Changes in Urbanization Process: A Case Study in Suzhou, China. J. Indian Soc. Remote Sens. 2010, 38, 654-663. [CrossRef]

25. Nichol, J.E. Visualisation of urban surface temperatures derived from satellite images. Int. J. Remote Sens. 1998, 19, 1639-1649. [CrossRef]

26. $\mathrm{Xu}, \mathrm{S}$. An approach to analyzing the intensity of the daytime surface urban heat island effect at a local scale. Environ. Monit. Assess. 2009, 151, 289-300. [CrossRef]

27. Abreu-Harbich, L.V.; Labaki, L.C.; Matzarakis, A. Thermal bioclimate in idealized urban street canyons in Campinas, Brazil. Theor. Appl. Climatol. 2013. [CrossRef]

28. Ali-toudert, F.; Djenane, M.; Bensalem, R.; Mayer, H. Outdoor thermal comfort in the old desert city of Beni-Isguen, Algeria. Clim. Res. 2005, 28, 243-256. [CrossRef]

29. Gabriel, K.M.A.; Endlicher, W.R. Urban and rural mortality rates during heat waves in Berlin and Brandenburg, Germany. Environ. Pollut. 2011, 159, 2044-2050. [CrossRef]

30. Tan, J.; Zheng, Y.; Tang, X.; Guo, C.; Li, L.; Song, G.; Zhen, X.; Yuan, D.; Kalkstein, A.J.; Li, F.; et al. The urban heat island and its impact on heat waves and human health in Shanghai. Int. J. Biometeorol. 2010, 54, 75-84. [CrossRef] [PubMed]

31. Lima, M.S.; Anjos, M.W.B.; Ramos, P.H.; Alves, E.D.L. Temperatura do ar no meio urbano: primeiros experimentos em Ceres - Goiás. Rev. Bras. Climatol. 2020, 26, 286-295. [CrossRef]

32. Mihalakakou, G.; Flocas, H.; Santamouris, M.; Helmis, C.G. Application of Neural Networks to the Simulation of the Heat Island over Athens, Greece, Using Synoptic Types as a Predictor. J. Appl. Meteorol. 2002, 41, 519-527. [CrossRef]

33. Saitoh, T.S.; Shimada, T.; Hoshi, H. Modeling and simulation of the Tokyo urban heat island. Atmos. Environ. 1996, 30, 3431-3442. [CrossRef]

34. Stewart, I.D.; Oke, T.R.; Krayenhoff, E.S. Evaluation of the 'local climate zone' scheme using temperature observations and model simulations. Int. J. Climatol. 2013, 34, 1062-1080. [CrossRef]

35. Amorim, M.C.D.C.T.; Junior, J.C.U. Os climas das cidades e as relações Sociedade/Natureza. Rev. Anpege 2016, 12, 252-278. [CrossRef]

36. Oke, T. City size and the urban heat island. Atmos. Environ. 1973, 7, 769-779. [CrossRef]

37. Coseo, P.; Larsen, L. How factors of land use/land cover, building configuration, and adjacent heat sources and sinks explain Urban Heat Islands in Chicago. Landsc. Urban Plan. 2014, 125, 117-129. [CrossRef]

38. Tan, M.; Li, X. Quantifying the effects of settlement size on urban heat islands in fairly uniform geographic areas. Habitat Int. 2015, 49, 100-106. [CrossRef]

39. Monteiro, C. A Dinâmica Climática e as Chuvas no Estado de São Paulo : Estudo Geográfico Sob Forma de Atlas; Instituto de Geografia: São Paulo, Brazil, 1973.

40. Embrapa, Banco de Dados Climáticos do Brasil. 2019. Available online: https://www.cnpm.embrapa.br/ projetos/bdclima/balanco/resultados/sp/451/balanco.html (accessed on 17 January 2019). 
41. Zen, G.; de Figueiredo Neves, G.Z.; Alves, E.D.L.; dos Santos, B.C.; Vecchia, F.A.S. Variabilidade e mudanças climáticas: Análise da tendência da precipitação na estação climatológica do CRHEA/USP em Itirapina-SP. In Proceedings of the XII Simpósio Brasileiro de Climatologia Geográfica, Goiania, Brazil, 25-29 October 2016; pp. 2673-2683. Available online: http://www.abclima.ggf.br/sbcg2016/anais/arquivos/eixo_6/trabalho(34).pdf (accessed on 21 April 2020).

42. Barbosa, R.V.R. Estudo do Campo Térmico Urbano de São Carlos (SP): Análise da Intensidade da Ilha de Calor Urbano em Episódio Climático de Verão; Universidade de São Paulo: São Paulo, Brazil, 2009.

43. IBGE, Cidades. 2018. Available online: http://www.cidades.ibge.gov.br/ (accessed on 1 May 2020).

44. Bere, T.; Tundisi, J.G. Epipsammic Diatoms in Streams Influenced by Urban Pollution, São Carlos, SP, Brazil. Braz. J. Biol. 2010, 70, 920-930. [CrossRef] [PubMed]

45. Barbosa, R.V.R.; Vecchia, F. Estudos de ilha de calor urbana por meio de imagens do Landsat 7 ETM + : Estudo de caso em São Carlos (SP). Minerva 1996, 6, 273-278. Available online: http://www.fipai.org.br/ Minerva06(03)07.pdf (accessed on 6 May 2020).

46. USGS, Earth Explorer. 2016. Available online: http://earthexplorer.usgs.gov/ (accessed on 1 August 2016).

47. Ndossi, M.I.; Avdan, U. Application of Open Source Coding Technologies in the Production of Land Surface Temperature (LST) Maps from Landsat: A PyQGIS Plugin. Remote Sens. 2016, 8, 431. [CrossRef]

48. Ndossi, M.I.; Avdan, U. "Inversion of Land Surface Temperature (LST) Using Terra ASTER Data: A Comparison of Three Algorithms. Remote Sens. 2016, 8, 993. [CrossRef]

49. Zhang, X.; Zhong, T.; Feng, X.; Wang, K. Estimation of the relationship between vegetation patches and urban land surface temperature with remote sensing. Int. J. Remote Sens. 2009, 30, 2105-2118. [CrossRef]

50. USGS, Using the USGS Landsat 8 Product. Available online: http://landsat.usgs.gov/Landsat8_Using_php (accessed on 1 May 2020).

51. Srivastava, P.K.; Han, D.; Rico-Ramirez, M.A.; Bray, M.; Islam, T.; Gupta, M.; Dai, Q. Estimation of land surface temperature from atmospherically corrected LANDSAT TM image using 6S and NCEP global reanalysis product. Environ. Earth Sci. 2014, 72, 5183-5196. [CrossRef]

52. Fotheringham, A.S.; Brunsdon, C.; Charlton, M. Geographically Weighted Regression: The Analysis of Spatially Varying Relationships; Wiley: New York, NY, USA, 2002.

53. Foody, G.M. Geographical weighting as a further refinement to regression modelling: An example focused on the NDVI-rainfall relationship. Remote Sens. Environ. 2003, 88, 283-293. [CrossRef]

54. Zhang, J.; Wang, Y.; Li, Y. A C++ program for retrieving land surface temperature from the data of Landsat TM/ETM+ band6. Comput. Geosci. 2006, 32, 1796-1805. [CrossRef]

55. Artis, D.A.; Carnahan, W.H. Survey of emissivity variability in thermography of urban areas. Remote Sens. Environ. 1982, 12, 313-329. [CrossRef]

56. Sinha, S.; Pandey, P.C.; Sharma, L.K.; Nathawat, M.S.; Kumar, P.; Kanga, S. Remote Estimation of Land Surface Temperature for Different LULC Features of a Moist Deciduous Tropical Forest Region; Springer: Berlin, Germany, 2014; pp. 57-68.

57. Cao, X.; Onishi, A.; Chen, J.; Imura, H. Quantifying the cool island intensity of urban parks using ASTER and IKONOS data. Landsc. Urban Plan. 2010, 96, 224-231. [CrossRef]

58. Li, S.; Mo, H.; Dai, Y. Spatio-temporal Pattern of Urban Cool Island Intensity and Its Eco-environmental Response in Chang-Zhu-Tan Urban Agglomeration. Commun. Inf. Sci. Manag. Eng. 2011, 1, 1-6.

59. Rasul, A.; Balzter, H.; Smith, C. Spatial variation of the daytime Surface Urban Cool Island during the dry season in Erbil, Iraqi Kurdistan, from Landsat 8. Urban Clim. 2015, 14, 176-186. [CrossRef]

60. Cheval, S.; Dumitrescu, A. The summer surface urban heat island of Bucharest (Romania) retrieved from MODIS images. Theor. Appl. Climatol. 2014, 121, 631-640. [CrossRef]

61. Debbage, N.; Shepherd, J.M. The urban heat island effect and city contiguity. Comput. Environ. Urban Syst. 2015, 54, 181-194. [CrossRef]

62. Li, S.; Zhao, Z.; Miaomiao, X.; Wang, Y. Investigating spatial non-stationary and scale-dependent relationships between urban surface temperature and environmental factors using geographically weighted regression. Environ. Model. Softw. 2010, 25, 1789-1800. [CrossRef]

63. INPE, TOPODATA. Available online: http://www.webmapit.com.br/inpe/topodata/ (accessed on 21 May 2020). 
64. Trentin, R.; Robaina, L.E.D.S.; Baratto, D.D.S. Análise de elementos do relevo através do Topographic Position Index (TPI) da bacia hidrográfica do arroio Puitã-Oeste do Rio Grande do Sul/Brasil. Rev. Dep. Geogr. 2016, 31, 14-25. [CrossRef]

65. Ivajnšič, D.; Kaligarič, M.; Žiberna, I. Geographically weighted regression of the urban heat island of a small city. Appl. Geogr. 2014, 53, 341-353. [CrossRef]

66. Paszynski, J. Mapping urban topoclimates. Energy Build. 1991, 16, 1059-1062. [CrossRef]

67. Kawamura, M.; Jayamanna, S.; Tsujiko, Y. Relation Between Social and Environmental Conditions in Colombo, Sri Lanka and the Urban Index Estimated by Satellite Remote Sensing Data. Int. Arch. Photogramm. Remote Sens. 1996, XXXI, 321-326. Available online: http://scholar.google.com/scholar?hl=en\&btnG= Search\&q=intitle:Relation+Between+social+and+environmental+conditions+in+Colombo, +Sri+Lanka+ and+the+urban+index+estimated+by+satellite+remote+sensing+data\#0 (accessed on 13 June 2020).

68. McFeeters, S.K. The use of the Normalized Difference Water Index (NDWI) in the delineation of open water features. Int. J. Remote Sens. 1996, 17, 1425-1432. [CrossRef]

69. Alves, E.D.L. Quantifying the effect of waterways and green areas on the surface temperature. Acta Sci. Technol. 2017, 39, 89. [CrossRef]

70. Carfan, A.C.; Galvani, E.; Nery, J.T. Study of the microclimate effect in the urban vertical structure in Ourinhos, São Paulo State. Acta Sci. Technol. 2012, 34, 313-320. [CrossRef]

71. Skoulika, F.; Santamouris, M.; Kolokotsa, D.; Boemi, N. On the thermal characteristics and the mitigation potential of a medium size urban park in Athens, Greece. Landsc. Urban Plan. 2014, 123, 73-86. [CrossRef]

72. Mendonça, F.; Dubreuil, V. Termografia de superfície e temperatura do ar na RMC (Região Metropolitana de Curitiba/PR). RaegaO Espaço Geográfico em Análise 2005, 9, 25-35. [CrossRef]

73. Jauregui, E. Influence of a large urban park on temperature and convective precipitation in a tropical city. Energy Build. 1990, 15, 457-463. [CrossRef]

74. Anjos, M.; Lopes, A.; Alves, E.D.L.; de Lucena, A.J. Rede climatológica urbana aplicada ao estudo da ilha de calor em Aracaju-SE. Caminhos Geogr. 2017, 18, 203-216. [CrossRef]

75. Junior, J.C.U.; Amorim, M.C.C.T. Clima urbano em Jales/SP: Características da temperatura e da umidade relativa em episódios de inverno. Rev. Geográfica América Cent. 2011, 2, 1-25.

76. Alves, E.D.L. Ilha de calor urbana em cidade de pequeno porte e a influência de variáveis geourbanas. Rev. Bras. Climatol. 2017, 20, 97-116. [CrossRef]

77. Alves, E.D.L.; Vecchia, F.A.S.; De Lima, E.A.; Anjos, M.; Mariano, Z.D.F. A temperatura do ar e umidade absoluta em cidade de pequeno porte: Características espaciais e temporais. Acta Sci. Hum. Soc. Sci. 2016, 38, 219. [CrossRef]

78. Lopes, A. Drenagem e acumulação de ar frio em noites de arrefecimento radiativo. Um exemplo no vale de Barcarena (Oeiras). Finisterra 2012, 30, 149-164. [CrossRef]

79. Buyantuyev, A.; Wu, J. Urban heat islands and landscape heterogeneity: Linking spatiotemporal variations in surface temperatures to land-cover and socioeconomic patterns. Landsc. Ecol. 2009, 25, 17-33. [CrossRef]

80. Haashemi, S.; Weng, Q.; Darvishi, A.; Alavipanah, S.K. Seasonal Variations of the Surface Urban Heat Island in a Semi-Arid City. Remote Sens. 2016, 8, 352. [CrossRef]

81. Lazzarini, M.; Marpu, P.R.; Ghedira, H. Remote Sensing of Environment Temperature-land cover interactions: The inversion of urban heat island phenomenon in desert city areas. Remote Sens. Environ. 2013, 130, 136-152. [CrossRef]

82. Becerra, J.A.B.; Shimabukuro, Y.E.; Alvalá, R.C.D.S. Relação do padrão sazonal da vegetação com a precipitação na região de cerrado da Amazônia Legal, usando índices espectrais de vegetação. Rev. Bras. Meteorol. 2009, 24, 125-134. [CrossRef]

83. Bernatzky, A. The contribution of tress and green spaces to a town climate. Energy Build. 1982, 5, 1-10. [CrossRef]

84. Oliveira, S.; Andrade, H.; Vaz, T. The cooling effect of green spaces as a contribution to the mitigation of urban heat: A case study in Lisbon. Build. Environ. 2011, 46, 2186-2194. [CrossRef]

85. Altman, D.G.; Bland, J.M. Absence of evidence is not evidence of absence. BMJ 1995, 311, 485. [CrossRef]

86. Deilami, K.; Kamruzzaman; Hayes, J.F. Correlation or Causality between Land Cover Patterns and the Urban Heat Island Effect? Evidence from Brisbane, Australia. Remote Sens. 2016, 8, 716. [CrossRef] 
87. Lee, L.; Chen, L.; Wang, X.; Zhao, J. Use of Landsat TM/ETM+ Data to Analyze Urban Heat Island and Its Relationship with Land Use/Cover Change. In Proceedings of the 2011 International Conference on Remote Sensing, Environment and Transportation Engineering, Nanjing, China, 24-26 June 2011; pp. $922-927$. [CrossRef]

88. Tyubee, B.T.; Anyadike, R.N.C. Investigating the Effect of Land Use/Land Cover on Urban Surface Temperature in Makurdi, Nigeria. In Proceedings of the ICUC9-9th International Conference on Urban Climate Jointly with 12th Symposium on the Urban Environment, Toulouse, France, 20-24 July 2015; pp. 1-15.

89. Chen, X.; Zhang, Y. Impacts of urban surface characteristics on spatiotemporal pattern of land surface temperature in Kunming of China. Sustain. Cities Soc. 2017, 32, 87-99. [CrossRef]

90. Flores, R.J.L.; Filho, A.J.P.; Karam, H.A. Estimation of long term low resolution surface urban heat island intensities for tropical cities using MODIS remote sensing data. Urban Clim. 2016, 17, 32-66. [CrossRef]

91. Rasul, A.; Balzter, H.; Smith, C.L. Diurnal and Seasonal Variation of Surface Urban Cool and Heat Islands in the Semi-Arid City of Erbil, Iraq. Climate 2016, 4, 42. [CrossRef]

92. Sun, D.; Kafatos, M. Note on the NDVI-LST relationship and the use of temperature-related drought indices over North America. Geophys. Res. Lett. 2007, 34, 24406. [CrossRef]

Publisher's Note: MDPI stays neutral with regard to jurisdictional claims in published maps and institutional affiliations.

(C) 2020 by the authors. Licensee MDPI, Basel, Switzerland. This article is an open access article distributed under the terms and conditions of the Creative Commons Attribution (CC BY) license (http://creativecommons.org/licenses/by/4.0/). 